\title{
The Differences in Body Volume and Skinfold Thickness Between Basketball Players and Footballers
}

\author{
Diferencias en el Volumen Corporal y el Grosor de los Pliegues \\ Cutáneos entre los Jugadores de Baloncesto y Jugadores de Fútbol
}

Agron M. Rexhepi \& Behlul Brestovci

REXHEPI, A. M. \& BRESTOVCI, B. The differences in body volume and skinfold thickness between basketball players and footballers. Int. J. Morphol., 28(4):1069-1074, 2010.

SUMMARY: The human body is composed of lean tissues that are metabolically active, and fat tissue that is not metabolically active, but is an essential part of human body. Training is a significant factor affecting body composition, performance, as well and physiological parameters. The aim of this study was through changeable of 13 measured anthropometrical variables, to research the influence of different sports in body composition. The anthropometrical tests were done on 90 basketball players and 512 footballers from Kosova. The gained results were analyzed in terms of basic statistical parameters, T-test, and Canonical Discriminant Analysis. Ttest shows that basketballers and footballers have realized significant differences in almost all measured variables. Canonical Discriminative Analysis indicates the characteristics of tested sportsmen: The basketballers are taller and heavier than footballers, as well they have the greater bodily volume, and more skinfold thickness, compared with footballers. It seems that the bodily volume of the tested basketballers has been influenced by the elements of basketball, than the bodily volume of footballers by the elements of football. As for subcutaneous adipose tissue that is less disperse on the footballers body compared with basketballers, could be explained with different ratio between aerobic and anaerobic demands of different sports.

KEY WORDS: Body composition; Basketball; Football; T-test; Canonical Discriminant Analysis.

\section{INTRODUCTION}

The human body is composed of lean tissues (muscle, bone, and organs) that are metabolically active, and fat (adipose) tissue that is not. Fat is an essential part of the human body and necessary to provide energy for long-duration physical activities. But, exceeding amount of fat is associated with diabetes and coronary heart disease. Knowing bodily composition of a sportsman allows us to plan his physical exercises, and dietary programme. A combination of a good programmed diet, as well and well organized physical exercises, will result in changes of bodily composition. However, changes of bodily composition of a person may not be so simple, and will depend on intensity, frequency, duration and applied time of physical exercises, as well how easy it is to change diet.

The body mass index (BMI) is a statistical measurement which compares a person's weight and height, respectively ratio between body weight and square of body height. This index is not a tool for diagnosis, but it can be used to estimate the healthy weight. BMI will change depending on gender, race, and age. A sportsman could have the same BMI as a non-sportsman, but his BMI will be due to increased muscle mass, than a rise in bodily fat. This fact makes it important that BMI should be used in association with other tools for measuring body fat (Reilly \& Williams, 2005).

Body weight is a three anthropometrical dimensional measure, respectively, a composite of independently varying tissues, which can be studied at several levels from basic chemical elements and specific tissues to the entire body (Malina, 2007).

Perimeters of the limbs and trunk are occasionally used as relative indicators of muscularity. Skinfold thickness 
is an indicator of subcutaneous adipose tissue (the portion of body fat located immediately beneath the skin). This thickness, in the form of double fold of skin and underlying subcutaneous tissue, can be measured with special calipers. According to the American College of Sports Medicine, skinfold measurements of body fat are up to $98 \%$ accurate, especially, when performed by a trained and skilled person (Lupash, 2009).

Body weight, body perimeters, as well and the subcutaneous adipose tissues, are about 50\% under control of the genotype factor, respectively about $50 \%$ may be affected by external factors (nourishment, level of physical activities, behaviors, environmental factors, cultural factors, socio-economical factors, etc.) (Brodie et al., 1998). All these anthropometrical measurements are very changeable, and during different periods of life, as well and under influence of different external and genetic factors may vary.

Some activity is better than none, and more activity (up to a point) is better than less. Recent studies indicate that good organized physical activities might have a positive impact on growth and development of circular variables of the body, as well and on the decrease of subcutaneous adipose tissue, in athletes. Numerous laboratory based studies have quantified the many health and fitness benefits (physiologic, metabolic and psychological benefits) associated with longduration exercise training (Lupash). The other benefits of regular endurance exercises are: lower death rates from coronary artery disease, lower incidence rates for combined cardiovascular diseases, coronary artery disease, cancer of colon, type 2 diabetes, decreased anxiety and depression, enhanced feelings of well-being, enhanced performance of work, recreational and sport activities, etc. (Lupash; McArdle et al., 1996).

Football is a sport that requires physical performance skills as well as tactical and technical expertise. Helgerud indicates a significant correlation between maximal oxygen consumption $\left(\mathrm{VO}_{2} \max \right)$ and elite soccer team performance (Helgerud et al.). According to recent studies, the average work intensity during a football match is usually about $75-90 \%$ of maximum heart rate, respectively $70-85 \%$ of $\mathrm{VO} 2 \mathrm{max}$ (approximately $75 \%$ of $\mathrm{VO}_{2} \max$ ). Whereas the average works intensity of basketball game is above $80 \%$ of $\mathrm{VO}_{2} \max$, respectively above 85\% of maximal heart rate (Balciunas, 2006; Nudri et al., 1996; Reilly \& Williams).

The basketball game contains different elements compared with the football game (more running, jumping, and extending). Jumping ability of the basketball players depends on their strong thigh and calf muscles,players need to have strong hips to hyperextend their legs and propel the body forward as well. Strong abdominal muscles and upper body, as well upper extremities allow basketballers to throw their body up into the air. Combination of all these muscle movements, indicate the importance of explosive force, speed, level of aerobic endurance, and anaerobic abilities, which basketballers should possess to make their game.

The aim of this study was to explore the influence of different sports (basketball and football) in growth and development of the anthropometrical variables, which inform about volume and distribution of the subcutaneous adipose tissue of athletes.

\section{MATERIAL AND METHOD}

This research is a part of the project: "The functional abilities of athletes from Kosova", realized in Center for Sports Medicine and Recreation in Prishtina, Kosova.

In this study anthropometrical tests were done on 602 sports players, with an average age of 21 years. Stature and body weight show diurnal variation, stature is greatest in the morning, whilst body weight is lighter. According to this, and in an attempt to avoid error during measurements, the sports players were measured in the morning hours $(08.00$ -11.00 AM).

To explore the influence of different sports in development of changeable of anthropometrical characteristics of youth, the measured entities were divided in two groups:

Group I: 90 professional basketball players, average aged 20.6 years old.

Group II: 512 professional footballers, average aged 21.1 years old.

The measurements were done in the Center of Sports Medicine and Recreation in Prishtina - Kosova, during the period $2007-2009$.

The following 13 variables were measured, according to the definitions of International Biological Program, using the classic anthropometrical instruments (anthropometer, classic weigher, milimetric tape, and skinfold caliper):

Stature: Body height measures the distance from the standing surface to the top (vertex) of the skull.

BMI: Body mass represents the ratio between body weight in $\mathrm{kg}$ 
and square body height in $\mathrm{m}^{2}$. BMI is used to estimate a healthy body weight based on how tall a person is.

Body volume and weight variables:

Body Weight: Is a measure of body mass.

Humeral Perimeter: shows maximum circumference of the arm (humerus).

Chest Perimeter: shows maximum circumference of the thorax at the mammilla level.

Abdominal Perimeter: shows circumference of the abdomen at the umbilicus level.

Thigh Perimeter: shows maximum circumference of the thigh.

Calf Perimeter: shows maximum circumference of the calf.

Skinfold thickness variables:

Triceps Skinfold: shows subcutaneous adipose tissue on the back of the arm (humerus) over the triceps muscle.

Subscapular Skinfold: shows subcutaneous adipose tissue on the back just below the inferior angle of scapula.

Abdomial Skinfold: shows subcutaneous adipose tissue of the abdomen at the umbilicus level $5 \mathrm{~cm}$ on the left.
Thigh Skinfold: shows subcutaneous adipose tissue on the thigh.

Calf Skinfold: shows subcutaneous adipose tissue on the calf, measured at the same level like calf's perimeter.

The obtained results were analyzed in terms of basic statistical parameters, T-test, and Discriminant Canonical Analyzes.

\section{RESULTS AND DISCUSION}

The essential descriptive statistical findings (Mean values, and their Standard Deviation), as well T-test value with Significance, calculated for each variable between two measured groups, are shown on Table I. On the basis of data of this table, we can note systematic differences in all measured variables between the basketball players and footballers that were tested. Systematic differences between two groups of athletes in abdominal skinfold variable (Sig. $=0.13)$ and in body mass index variable $($ Sig. $=0.21)$ are not statistically significant. Whereas, all other systematic differences of measured variables are statistically significant (Sig. $=0.00-0.02)$.

Table II shows the international classification, respectively categorization of the BMI values according to

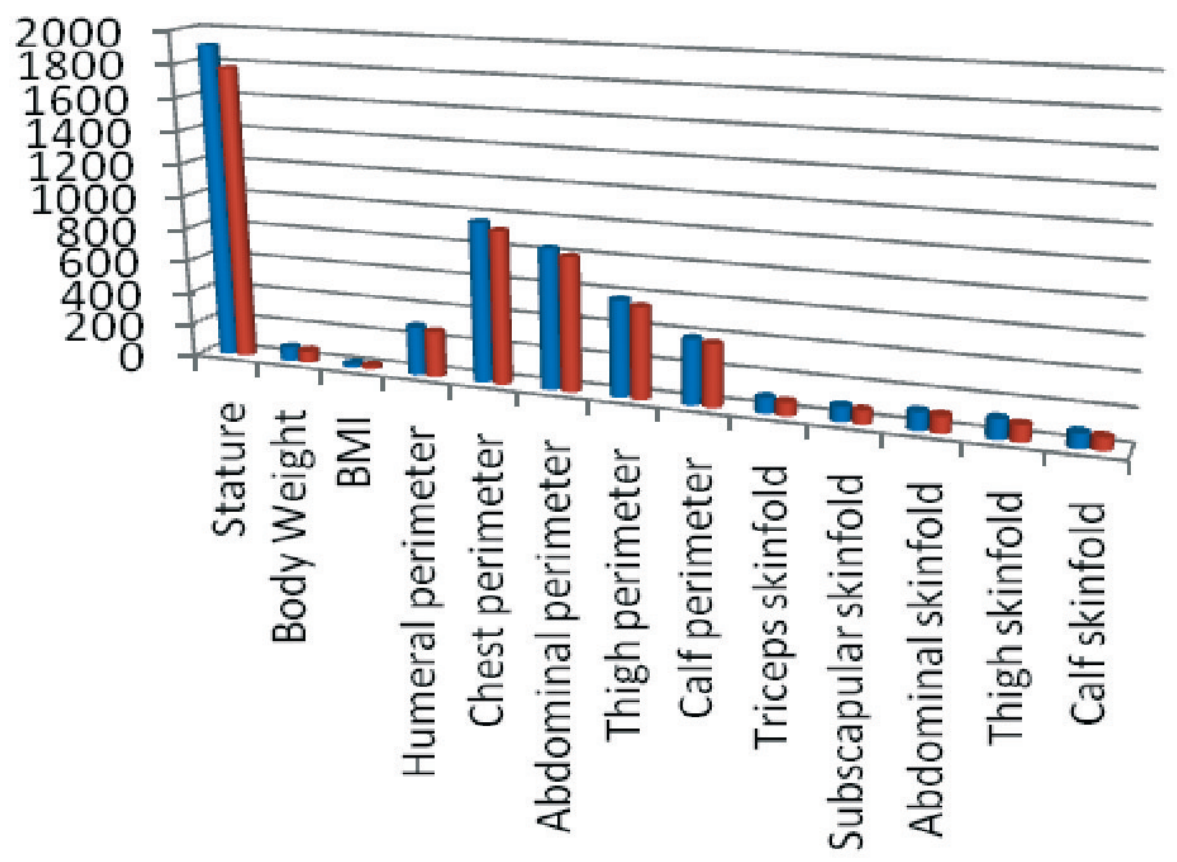

Basketball. Football.

Fig. 1. Shows graphically presentation of measured variables. By this graph we can see the variables that better discriminate these two groups of athletes. 
REXHEPI, A. M. \& BRESTOVCI, B. The differences in body volume and skinfold thickness between basketball players and footballers. Int. J. Morphol., 28(4):1069-1074, 2010.

Table I. Descriptive statistic and T-test.

\begin{tabular}{|c|c|c|c|c|c|}
\hline V ariables & SPORT & Mean & Standard Deviation & $\mathbf{t}$ & Sig. \\
\hline \multirow[t]{2}{*}{ Stature } & Basketball. & 1909.74 & 85.42 & 16.99 & 0.00 \\
\hline & Footballer & 1781.03 & 62.36 & & \\
\hline \multirow[t]{2}{*}{ Body Weight } & Basketball. & 83.05 & 11.97 & 16.99 & 0.00 \\
\hline & Footballer & 71.19 & 8.03 & & \\
\hline \multirow[t]{2}{*}{ BMI } & Basketball. & 22.71 & 2.59 & 1.25 & 0.21 \\
\hline & Footballer & 22.41 & 1.97 & & \\
\hline \multirow[t]{2}{*}{ Humeral perimeter } & Basketball. & 294.31 & 30.52 & 6.49 & 0.00 \\
\hline & Footballer & 277.65 & 20.64 & & \\
\hline \multirow[t]{2}{*}{ Chest perimeter } & Basketball. & 965.90 & 67.30 & 6.41 & 0.00 \\
\hline & Footballer & 925.92 & 51.87 & & \\
\hline \multirow[t]{2}{*}{ Abdominal perimeter } & Basketball. & 844.87 & 66.79 & 6.30 & 0.00 \\
\hline & Footballer & 806.35 & 50.65 & & \\
\hline \multirow[t]{2}{*}{ Thigh perimeter } & Basketball. & 579.73 & 47.73 & 6.27 & 0.00 \\
\hline & Footballer & 551.74 & 37.22 & & \\
\hline \multirow[t]{2}{*}{ Calf perimeter } & Basketball. & 393.01 & 34.22 & 6.87 & 0.00 \\
\hline & Footballer & 373.99 & 21.94 & & \\
\hline \multirow[t]{2}{*}{ Triceps skinfold } & Basketball. & 93.27 & 48.63 & 4.19 & 0.00 \\
\hline & Footballer & 77.79 & 28.40 & & \\
\hline \multirow[t]{2}{*}{ Subscapular skinfold } & Basketball. & 90.02 & 36.95 & 3.85 & 0.00 \\
\hline & Footballer & 79.44 & 20.92 & & \\
\hline \multirow[t]{2}{*}{ Abdominal skinfold } & Basketball. & 108.77 & 69.16 & 1.40 & 0.16 \\
\hline & Footballer & 99.82 & 52.93 & & \\
\hline \multirow[t]{2}{*}{ Thigh skinfold } & Basketball. & 115.89 & 68.39 & 3.25 & 0.00 \\
\hline & Footballer & 96.69 & 48.06 & & \\
\hline \multirow[t]{2}{*}{ Calf skinfold } & Basketball. & 86.97 & 42.42 & 2.45 & 0.02 \\
\hline & Footballer & 78.53 & 27.30 & & \\
\hline
\end{tabular}

the WHO. The comparison of the BMI values (Table I), which have been realized by football players and basketball players, with data of Table II, enables evaluation of their healthy weight.

While, differences in each measured variable, between basketball players and footballers have been tested by T-test, the multidimensional differences, between these tested groups, respectively their group characteristics have been defined by Canonical Discriminant Analyses (Table III).

Through Canonical Discriminant Analyses (Table III) has been extracted one significant discriminant function (Sig. $=0.000$ ), and eigenvalue of the discriminative equation $1=$ 0.610 . The canonical correlation of this discriminant function with system of measured variables was $\mathrm{Rc}=0.615$.
Table II. The International Classification of adult underweight, overweight and obesity according to BMI.

\begin{tabular}{ll}
\hline Category & BMI range $-\mathbf{~ k g} / \mathbf{m}^{\mathbf{2}}$ \\
\hline Severely underweight & less than 16.5 \\
Underweight & $16.5-18.4$ \\
Normal & $18.5-24.9$ \\
Overweight & $25-30$ \\
Obese Class I & $30.1-34.9$ \\
Obese Class II & $35-40$ \\
Obese Class III & Over 40 \\
\hline
\end{tabular}

The discriminant force of the measured variables has been assisted by Wilks'l $=0.621$, whereas the statistical significance of the discriminative equation has been tested by BartletX2test $\mathrm{X} 2=275.923$. 
REXHEPI, A. M. \& BRESTOVCI, B. The differences in body volume and skinfold thickness between basketball players and footballers. Int. J. Morphol., 28(4):1069-1074, 2010.

Table III. Canonical discriminative function and group centroids.

\begin{tabular}{|c|c|c|c|c|c|c|c|}
\hline \multirow[t]{2}{*}{ Function } & \multirow[t]{2}{*}{ - } & \multirow[t]{2}{*}{$\mathrm{Rc}$} & \multirow[t]{2}{*}{ Wilks'_ } & \multirow{2}{*}{$\begin{array}{l}\text { Bartlet } \\
X^{2} \text {-test }\end{array}$} & \multirow[t]{2}{*}{ Sig. } & \multicolumn{2}{|c|}{ Group centroids } \\
\hline & & & & & & Football. & Basketball \\
\hline 1 & .610 & .615 & .621 & 275.923 & .000 & -.331 & 1.834 \\
\hline
\end{tabular}

The significant value of the extracted discriminative function (Sig. $=0.000$ ) indicate validity of differences between two athletes-groups tested.

The values of group-centroids (Table III), and the structural matrix (Table IV), enable us to discover the variables, which determine the characteristics of the two tested athletes-groups, respectively, which discriminate these two groups.

According to data of Tables III and IV, the extracted discriminative function may be nominated as "factor of bodily volume". Also, we can conclude that the morphology of the basketball players is characterized with higher body weight and height, as well body volume, compared with footballers.

In conclusion, body composition changes during the competitive season as a result of athletes activities. Training is a significant factor affecting body composition, performance, as well as physiological parameters. Some of the physical variations between different athletes represent an interaction between individual characteristics, and selective impacts of different elements of different sports (Power \& Howley, 2001; Kraemer et al., 2005).

Strength, endurance, flexibility, coordination, speed, balance, quantity of the physical exercises (intensity, duration, frequency), as well experience of the athletes are the essential motor criteria in distinguishing morphometrical characteristics, respectively body composition of the athletes (Bompa, 1983; Erith; McArdle et al.; Rexhepi).

Table I shows variables that significantly differentiate two groups of the athletes. The differences in body height and body weight, between the basketballers and the footballers, can be explained with basic requests of basketball sport. In general, the basketballers are taller and heavier than the footballers.

Even if two tested groups of the athletes show significant differences in body height and weight, on BMI (Body Mass Index) they are similar. Thus, the ratio between their bodily weight and height is similar for both tested groups, as well as according to the data of Table II, we can conclude that they have normal and healthy bodily weight.
Whereas T-test (Table I) shows one-dimensional differences in almost all measured variables (except BMI and abdominal skinfold thickness), the Canonical Discriminative Analyzes (Table III, IV) shows multi-dimensional differences between groups, respectively the characteristics of the athletes that were tested. According to the data of table IV, which show the more important variables that discriminate the basketball players and the footballers, as well and to the data of table III, which show the position of the group centroids, the discriminative function could be nominated as "function of bodily volume". Based on the information that this function contains, we can notice the characteristics of the tested athletes groups: The basketballers are taller and heavier than footballers, as well as they've the biggest bodily volume, and more subcutaneous adipose tissue, compared with footballers.

As, the dimensions of bodily volume and subcutaneous adipose tissue are about $50 \%$ controlled by the endogen factors (genotype), these two bodily dimensions may be changed by the influence of external factors (Rexhepi). According to the results of our study, it seems that the bodily volume of the tested basketballers has been more influenced by the elements of basketball, than the bodily volume of footballers by the elements of football. As for subcutaneous adipose tissue that is less disperse on the footballers body, compared with basketballers, could be explained with the ratio between aerobic

Table IV. Shows values of correlation for each measured variables that realize with the discriminative function.

\begin{tabular}{ll}
\hline Variables & Function 1 \\
\hline Stature & 890 \\
Body weight & 625 \\
Calf perimeter & .362 \\
Humeral perimeter & .342 \\
Chest perimeter & .338 \\
Abdominal perimeter & .333 \\
Thigh perimeter & .331 \\
Triceps skinfold & .222 \\
Subscapular skinfold & .204 \\
Thigh skinfold & .171 \\
Calf skinfold & .130 \\
Abdominal skinfold & .075 \\
BMI & .065 \\
\hline
\end{tabular}


and anaerobic demands of different sports (the footballers about 70\%: 30\%; the basketballers about 90\%:10\%) (Balciunas et al.; Nudri et al.; Reilly \& Williams). Also, basketballers engage larger number of their muscles during their physical activities, compared with footballers.
All these elements, as well and specifics of basketball sport, justify the physical characteristics of a basketball player as a person with greater bodily dimensions, and with higher values of skinfold thickness, compared with a footballer.

REXHEPI, A. M. \& BRESTOVCI, B. Diferencias en el volumen corporal y el grosor de los pliegues cutáneos entre los jugadores de baloncesto y jugadores de fútbol. Int. J. Morphol., 28(4):1069-1074, 2010.

RESUMEN: El cuerpo humano se compone de tejido blando que es metabólicamente activo y tejido graso que no es metabólicamente activo, pero es una parte esencial del cuerpo. El entrenamiento es un factor significativo que afecta la composición corporal, el rendimiento y los parámetros fisiológicos. El objetivo de este estudio fue investigar la influencia de los diferentes deportes en la composición corporal, a través de la medición de 13 variables antropométricas. Las pruebas antropométricas fueron realizadas en 90 jugadores de baloncesto y 512 jugadores de fútbol de la ciudad de Kosovo. Los resultados obtenidos fueron analizados estadísticamente utilizándose el T-test y el análisis discriminante canónico. El T-test mostró que los jugadores de baloncesto y los futbolistas poseen diferencias significativas en casi todas las variables estudiadas. El análisis discriminante canónico de las características de los deportistas evaluados mostraron que: los jugadores de baloncesto son más altos y de mayor peso que los futbolistas y tenían mayor volumen corporal y pliegues cutáneos en comparación con los futbolistas. El volumen corporal de los jugadores de baloncesto han sido más influenciados por los elementos del baloncesto, que el volumen corporal de los futbolistas por los elementos del fútbol. En cuanto a tejido adiposo subcutáneo, es menos disperso en el cuerpo de los futbolistas comparado con jugadores de baloncesto, lo que podría explicarse por una relación diferente entre las demandas aeróbica y anaeróbica exigidas en los diferentes deportes.

PALABRAS CLAVE: Composición corporal; Baloncesto; Fútbol; T-test; Análisis discriminante canónico.

\section{REFERENCES}

Balciunas, M.; Stonkus, S.; Abrantes, C. \& Sampaio. Long term effects of different training modalities on power, speed, skill and anaerobic capacity in young male basketball players. $J$. Sport Sci. Med., 5:163-70, 2006.

Bompa, T. O. Theory and methodology of training. In: Fox, J. (Ed.). The key to athletic performance. Dubuque, Kendall/Hunt Publishing Company, 1983.

Brodie, D.; Moscrip, V. \& Hutcheon, R. Body Composition Measurement:A Review of Hydrodensitometry, Anthropo-metry, and Impedance Methods. Nutrition, 14(3):296-310, 1998.

Erith, S. J. An overview of fitness testing within English professional football clubs. J. Sports Sci., 22:247, 2004.

Helgerud, J.; Engen, L. C.; Wisloff, U. \& Hoff, J. Aerobic endurance training improves soccer performance. Med. Sci. Sports Exerc., 33(11):1925-31, 2001.

Kraemer, W. J.; Torine, J. C.; Silvestre, R.; French, D. N.; Ratamess, N. A.; Spiering, B. A.; Hatfield, D. L.; Vingren, J. L. \& Volek, J. S. Body size and composition of National Football League players. J. Strength Cond. Res., 19(3):485-9, 2005.

Lupash, E. Acsm's guidelines for exercise testing and prescription. American College of Sports Medicine. $7^{\text {th }}$ Ed. Baltimore. Lippincott Williams \& Wilkins, 2009.

Malina, M. R. Body composition in athletes: assessment and estimated fatness. Clin. Sports Med., 26(1):37-68, 2007.
McArdle, W. D.: Katch, F. I. \& Katch, V. L. Exercise physiology. $4^{\text {th }}$. Ed. Baltimore, Meriland, Lippincott Williams\& Wilkins, 1996.

Nudri, W. D.; Ismail, M. N. \& Zawiak, H. Anthropometric measurements and body composition of selected national athletes. Mal. J. Nutr., 2:138-47, 1996.

Power, K. S. \& Howley, T. E. Exercise Physiology. $4^{\text {th }}$ edition. New York, McGraw Hill, 2001.

Reilly, T. \& Williams, M. A. Science and soccer. $2^{\text {nd }}$ Ed. New York, Routledge, 2005. pp.287-301.

Rexhepi, A. Textbook Mjekësia Sportive-Sports Medicine, p 27679. Mozaiku, Prishtina. WHO. BMI classification. http:// apps.who.int/bmi/index.jsp?introPage=intro_3.html. Retrived 01 November 2009.

\author{
Correspondence to: \\ Agron Rexhepi \\ Str. Sali Butka Nr. 31/D \\ Center of Sport Medicine and Recreation \\ Palace of Youth and Sport, Str. "Luan Haradinaj" nn. \\ Prishtina, 10020 \\ KOSOVA
}

Phone: +37744110855

Email: agronmrexhepi@gmail.com

Received: 23-07-2010

Accepted: 16-09-2010 